American Journal of Experimental Agriculture

5(5): 419-434, 2015, Article no.AJEA.2015.042

ISSN: 2231-0606

SCIENCEDOMAIN international

www.sciencedomain.org

\title{
Exogenous Cytokinin Promotes Epipremnum aureum L. Growth through Enhanced Dry Weight Assimilation rather than through Changes in Partitioning
}

\author{
A. Di Benedetto ${ }^{1,2^{*}}$, C. Galmarini $i^{3,4}$ and J. Tognetti $i^{2,5}$ \\ ${ }^{1}$ Faculty of Agronomy, University of Buenos Aires, Avenida San Martín 4453 (C1417DSE), \\ Buenos Aires, Argentina. \\ ${ }^{2}$ Faculty of Agricultural Sciences, National University of Mar del Plata, Balcarce, \\ Province of Buenos Aires, Argentina. \\ ${ }^{3}$ Faculty of Agricultural Sciences, National University of Cuyo and CONICET, Alt. Brown 500 \\ (M5528AHB), Chacras de Coria, Province of Mendoza, Argentina. \\ ${ }^{4}$ National Agricultural Technology Institute, EEA La Consulta, CC 8 (5567), The Consultation San \\ Carlos, Province of Mendoza, Argentina. \\ ${ }^{5}$ Research Commission of the Province of Buenos Aires, La Plata, Province of Buenos Aires, \\ Argentina.
}

Authors' contributions

This work was carried out in collaboration between all authors. All authors read and approved the final manuscript.

Article Information

DOI: $10.9734 / A J E A / 2015 / 13398$

Editor(s):

(1) Masayuki Fujita, Dept. of Plant Sciences, Faculty of Agriculture, Kagawa University, Japan.

Reviewers:

(1) Anonymous, Crop research institute, Czech Republic.

(2) Anonymous, Kocaeli University, Turkey.

Complete Peer review History: http://www.sciencedomain.org/review-history.php?iid=738\&id=2\&aid=6625

Original Research Article

Received $15^{\text {th }}$ August 2014

Accepted $24^{\text {th }}$ September 2014

Published 22 ${ }^{\text {nd }}$ October 2014

\section{ABSTRACT}

Aims: Benzylaminopurine (BAP) sprays have been shown to increase leaf size and leaf appearance rate, as well as biomass accumulation in pot-grown Epipremnum aureum L. BAP-mediated enhanced growth could either be the consequence of a higher investment of dry weight in leaf area development thus leading to a positive dry weight accumulation feedback, to a promoting effect on dry weight assimilation per unit leaf area.

Study Design: A randomized complete block factorial design with three blocks was used. 
Place and Duration of Study: Two experiments were carried out in a greenhouse at the Faculty of Agronomy, University of Buenos Aires, Argentina (34 $28^{\prime} S$ ) from the $8^{\text {th }}$ September 2007 and $5^{\text {th }}$ September 2008, respectively, to the $12^{\text {th }}$ March 2008 and $11^{\text {th }}$ March 2009 respectively.

Methodology: We analyzed the effect of exogenous BAP supplied in different number of applications and at different concentrations under three light intensities, on dry weight accumulation and partitioning in $E$. aureum grown in pots, in two greenhouse experiments.

Results: A single $5 \mathrm{mg} \mathrm{L}^{-1}$ BAP application was enough to increase the dry weight accumulation rate in comparison to untreated controls, irrespective of the light intensity. A strong direct relationship between the relative growth rate (RGR) and the net assimilation rate (NAR) were found, while an inverse relationship was observed between RGR and the leaf area ratio (LAR). Even though BAP increased dry weight partitioning to the aerial part, as revealed by shoot vs. root allometric analysis, this did not result in a LAR increase, but rather in higher stem dry weight accumulation, in association with a decrease in the leaf area partitioning coefficient (LAP). NAR promotion by BAP was associated with an increased $\mathrm{N}$ content per unit leaf area, rather than with changes in chlorophyll content.

Conclusion: Our results on the ornamental shade plant $E$. aureum also provide information which may help to increase productivity to this crop from a grower perspective.

Keywords: Cytokinin; foliage plant; leaf area partitioning; relative growth rate.

\section{INTRODUCTION}

Ornamental shade plants usually show low relative growth rates in terms of fresh weight, dry weight and leaf area [1]. The fact that this type of plants are usually grown in pots further limits their growth due to the root restriction syndrome, which has been associated with a reduced supply of cytokinins by the root [2]. In a previous paper [3], we have shown that exogenous benzylaminopurine (BAP) supply to pot-grown rooted-cuttings of Epipremnum aureum resulted in a promotion of shoot development, which included increases in final leaf area, in the rate of leaf appearance and in fresh weight accumulation. Since the dry matter content in tissues was unaffected by exogenous hormone supply, the increase rate in fresh weight accumulation indicates an increase in dry weightbased to the relative growth rate (RGR). In general, variation in RGR may be explained by changes in either the net assimilation rate (NAR) or in the leaf area ratio (LAR), depending on the source of variation in RGR. For example, when the cause of RGR variation is light intensity, NAR has been shown directly correlated with RGR [4] while an inverse relationship between LAR and RGR can be found [5]. On the other hand, working with 24 wild species, Poorter et al. [6] reported that differences in LAR explained species-inherent variation in RGR under comparable growing conditions, although Shipley [7] proposed that the effect of LAR and NAR could vary depending on light intensity (NAR becoming more important at higher irradiances). Furthermore, work on Aegilops and Triticum species revealed that the contribution of NAR and LAR to changes in RGR depended on the time-scale of measurements probably associated with the developmental stage of the crop [8]. Regarding the effect of exogenous BAP, available evidence does not allow to discern whether changes in LAR or NAR can explain a promoting effect of the hormone on RGR.

Cytokinin-driven diversion of assimilates and mineral nutrients towards shoot meristems, rather than to roots, ultimately resulting in a differential increase in aerial biomass has been reported for a wide number of species [9-13], including ornamental plants $[14,15]$. Plant tissues and organs rich in cytokinins, like the stem apical meristem, are known to attract photoassimilates [16]. Whether the promoting effect of cytokinins on shoot growth can be explained by an increased partitioning of resources to the aerial part should be tested by calculating the allometric coefficient between shoot and roots. Furthermore, cytokinins also affect meristem function and stem-cell identity in the center of shoot meristems [17] and exogenous supply of BAP to $E$. aureum plants has been shown to increase final leaf size and accelerate the rate of leaf appearance [3]. The promotion of leaf area development is an especially important "reinvestment" because it drives growth in an exponential fashion. One important parameter that accounts for this effect by relating leaf area development to available assimilates is the leaf area partitioning coefficient (LAP) [18]. Both changes in the shoot vs. root allometric coefficient, and/or in LAP, might explain changes 
in LAR that would ultimately explain the promoting effect of BAP on dry matter accumulation; however no reports about possible effects of cytokinins on these growth parameters are available in literature.

On the other hand, cytokinins are also known to enhance carbon fixation per unit leaf area [19]. Exogenously applied cytokinin to detached barley leaves has been shown to stimulate transcription of a wide number of chloroplast genes, including rbcL, which codes for Rubisco large subunit [20]. Cytokinins are also involved in chlorophyll biosynthesis [21]. Moreover, exogenous application of cytokinin [22] and overexpression of endogenous cytokinin in transgenic plants [23] have been reported to increase leaf thickness, which may further enhance dry weight accumulation per unit leaf area. Therefore, at least a part of the promoting effects of BAP application on RGR may be mediated by an increase in NAR. Besides, cytokinin effects on photosynthetic efficiency are mostly evident in low light intensity environments [10]. The cytokinin effect on chloroplast transcription depends on the presence of light [20]. In agreement with this, the exogenous supply of cytokinin in field environments is not always effective in promoting dry weight fixation; i.e. Hosseini et al. [24] found no increase in the photosynthetic rate or chlorophyll content of Hordeum vulgare of BAP-sprayed plants except at the late period of grain filling. In greenhouse grown E. aureum, BAP was found to promote leaf growth under three different light intensities, but the effect was especially high under the intermediate one [3]. Therefore, the magnitude of a possible promotion of NAR by BAP may depend on light intensity.

In this work we analyzed whether changes in dry weight assimilation and/or partitioning may explain the BAP-induced growth promotion of $E$. aureum rooted cuttings grown under greenhouse conditions with different light intensities and a number of BAP applications.

\section{MATERIALS AND METHODS}

\subsection{Plant Material, Treatments and Experiments}

Rooted cuttings of $E$. aureum were transplanted into 1.2L plastic pots (one cutting per pot) filled with a 1:1 (v/v) mix of Sphagnum maguellanicum peat and river waste [25]. Plants were watered daily and fertilized weekly with $\mathrm{N}, \mathrm{P}, \mathrm{K}$ and $\mathrm{Ca}$ fertilizer added to the irrigation water $\left(50 \mathrm{mg} \mathrm{L}^{-1} \mathrm{~N}\right)$ (1.0:0.5:1.0:0.5 N:P:K:Ca). Two experiments were carried out in a greenhouse at the Faculty of Agronomy, University of Buenos Aires, Argentina (34 $28^{\prime}$ 'S) from the $8^{\text {th }}$ September 2007 and $5^{\text {th }}$ September 2008, respectively, to the $12^{\text {th }}$ March 2008 and $11^{\text {th }}$ March 2009 respectively. The greenhouse was covered with a neutral black shade-cloth (for $50 \%$ full sunlight) (Agriplast S.A. Buenos Aires, Argentina) for the experiment in 2007-2008. In the 2008-2009 experiment, the greenhouse was divided into nine compartments with different neutral black shading clothes (Agriplast S.A. Buenos Aires, Argentina) to obtain irradiances equivalent to $70 \%, 50 \%$, or $30 \%$ of full sunlight (three compartments per light intensity). Light quality was not changed significantly (data not shown) by the shade-clothes, as confirmed using a $660 / 730$ sensor (Skye instruments, Wales, UK). Daily mean temperatures $\left({ }^{\circ} \mathrm{C}\right)$ and light intensities (mol photons $\mathrm{m}^{-2}$ day $^{-1}$ ) for the different experiments were recorded with three HOBO sensors (Onset Computer Corp. Bourne, MA, USA) connected to HOBO H8 data loggers. The plants arrangement at a density of 25 plants $\mathrm{m}^{-2}$ avoided mutual shading.

The benzylaminopurine (BAP) (SIGMA EC 214927-5) water solutions were applied by spraying all leaves to run-off at sunset (no wetting agent was added). For the 2007-2008 experiment plants were sprayed with 0 (control) or $5 \mathrm{mg} \mathrm{L}^{-1}$ BAP solutions 7 days after transplanting and spray was repeated one and two months afterwards, rendering four different treatments, 0 $0-0$; 5-0-0, 5-5-0 and 5-5-5mg L-1 BAP, which correspond to 0, I, II and III BAP applications, respectively. BAP concentration was chosen from a previous experiment performed in 20062007 [3]. In the 2008-2009 experiment plants were sprayed with 0 (control), $2.5,5,10$, or 50 $\mathrm{mg} \mathrm{L}^{-1}$ BAP solutions 7 days after transplanting.

\subsection{Growth Evaluations}

For destructive measurements, six plants per treatment and sampling date were randomly chosen at the beginning of the experiments (transplant stage) and 60, 90, 120, 150 and 180 days after transplanting. Separate plant parts (two plants per block) were dried at $80^{\circ} \mathrm{C}$ for 48 hours and weighed to obtain the dry weight of shoots (including leaf blades, petioles and stems) and roots. Leaf area was determined with a $\mathrm{LI}$ COR 3000A (LI-COR Inc., Lincoln, NE, USA) automatic leaf area meter, Leaf area at zero time 
and the relative leaf area expansion rate (RLAER) were calculated from the regression of the natural logarithm of total leaf area vs. time (in days).

Whole plant RGR was calculated as the slope of the linear regression of the natural logarithm of dry weight vs. time (in days). The net assimilation rate (NAR) which represents the rate of dry weight increase per unit leaf area and per unit time, and the leaf area partitioning coefficient (LAP), which represents the change in the leaf area ratio per unit time and, thus estimates the partitioning of assimilates into new leaf, were calculated according to Potter and Jones [18] as following:

$$
\begin{gathered}
N A R=\left(k_{w} W_{0} e^{k_{w} t}\right) /\left(A_{0} e^{k_{a} t}\right) \\
\operatorname{LAP}=\left(k_{a} A_{0} e^{k_{a} t}\right) /\left(k_{w} W_{0} e^{k_{w} t}\right)
\end{gathered}
$$

where: $\mathrm{k}_{\mathrm{w}}$ : RGR (days ${ }^{-1}$ ); $\mathrm{W}_{0}$ : extrapolated value of total dry weight at time zero $(\mathrm{g}) ; \mathrm{A}_{0}$ : extrapolated value of leaf area at time zero $\left(\mathrm{cm}^{2}\right) ; \mathrm{k}_{\mathrm{a}}$ : RLAER (days ${ }^{-1}$ ); t: time (in days) at the midpoint of the experimental period and e: base of natural logarithms.

Mean LAR was calculated as RGR/NAR. The components of LAR, specific leaf area (SLA) and leaf weight ratio (LWR) were obtained as follows: SLA was calculated as the ratio of individual leaf area to leaf dry weight (average of all plant leaves) while LWR was calculated as the ratio of whole plant leaf dry weight to whole plant dry weight, in both cases at the final sampling of the 2008-2009 experiment.

The allometric coefficients between root and shoot and between leaf blades and the petiolestem fraction were calculated as the slope $(\boldsymbol{\beta})$ of the straight-line regression of In root dry weight vs. In shoot dry weight (In Root dry weight $=\alpha+$ $\boldsymbol{\beta} \times$ In Shoot dry weight) and between In leaf blade dry weight and In (petiole+stem) dry weight (In Leaf blade dry weight $=\boldsymbol{\alpha}+\boldsymbol{\beta} \times \ln$ PetioleStem dry weight), respectively. For root-shoot allometry, data from the first sampling were excluded of the analysis because of their departure from linearity, which was likely the consequence of transplant effects on the root: Shoot ratio.

Chlorophyll analysis was performed on the youngest fully expanded leaf from plants at the final sampling of both experiments. Leaf disks were cut from the central area near the mid-vein of each leaf and placed in vials containing $3 \mathrm{~cm}^{3}$ of $\mathrm{N}, \mathrm{N}$-dimethylformamide. Leaf disks were vacuum-infiltrated and stored for three days in complete darkness. At this time, chlorophyll had completely eluted to the solvent and absorbance was measured at $647 \mathrm{~nm}$ and $664 \mathrm{~nm}$ using a Metrolab 1600 spectrophotometer. Chlorophyll content was calculated as indicated by Inskeep and Bloom [26].

Nitrogen analysis (Kjeldall method) was performed on the youngest fully expanded leaf from plants at the final sampling of the 20082009 experiment with a LB-UDK129 analyzer (Labometric, Buenos Aires, Argentina). Nitrogen was determined only in plants treated with 0 or $5 \mathrm{mg} \mathrm{L}^{-1}$ BAP.

\subsection{Statistical Analysis}

For growth analysis in both 2007-2008 and 20082009 experiments, plants were arranged in a randomized complete block design with three blocks and two plants per block, for each treatment and sampling date. Data were subjected to one-way ANOVA (2007-2008 experiment) or two-way ANOVA (2008-2009) experiment. For chlorophyll and nitrogen analysis, a similar experimental design was used, except that only one plant per block was sampled. Means were separated by Tukey's test $(\mathrm{P}<0.05)$. For allometric analysis, differences in slopes were tested using the SMATR package [27], since no significant block effects were found in any case, data points from all individual plants were included in this analysis.

\section{RESULTS}

\subsection{Climate}

The air temperatures ranged between 10.28$20.15^{\circ} \mathrm{C}$ (minimum) and $20.94-30.08^{\circ} \mathrm{C}$ (maximum) during the 2006-2007 experiment, between $12.68-20.69^{\circ} \mathrm{C}$ (minimum) and 21.38$30.62^{\circ} \mathrm{C}$ (maximum) during the 2007-2008 experiment and between $10.48-20.60^{\circ} \mathrm{C}$ (minimum) and $18.63-31.13^{\circ} \mathrm{C}$ (maximum) during the 2008-2009 experiment. Solar radiation ranged between 7.61 and $10.71 \mathrm{MJ} \mathrm{m}^{-2}$ day $^{-1}$ during the 2006-2007 experiment, between 6.34 and $10.99 \mathrm{MJ} \mathrm{m}^{-2}$ day $^{-1}$ during the $2007-2008$ experiment and between 5.93 and $11.79 \mathrm{MJ} \mathrm{m}^{-2}$ day $^{-1}$ during the 2008-2009 experiment (Table 1). 


\subsection{BAP Applications Number}

An increased accumulation of dry weight was observed in plants sprayed once, twice or three times with $5 \mathrm{mg} \mathrm{L}^{-1} \mathrm{BAP}$, in comparison to controls and the response was highest when BAP was applied just once. The effect of BAP was generally higher in shoots than in roots (Fig. 1), leading to decreased root: Shoot ratios from 0.56 in controls to 0.42 in BAP treated plants (Table 2).

Accordingly, the highest RGR values were found with only one BAP application, although all BAP treatments led to higher RGR than control plants. NAR was also highest in plants sprayed just once and decreased with subsequent BAP applications to a value close to control in plants sprayed three times. In fact, NAR was more promoted by BAP than RGR in plants sprayed just once (i.e. $27.3 \%$ vs. $18.9 \%$ increases in NAR and RGR, respectively) Conversely, plants sprayed just once had lower mean LAR and LAP values than controls and both variables tended to increase with further BAP sprays towards the values exhibited by control plants (Table 2). A close direct relationship between RGR and NAR $\left(r^{2}=0.972, \quad P<0.001\right)$ could be observed by plotting data from all treatments, while an inverse relationship between RGR and LAR [LAR = -3.71 RGR + $\left.153.32\left(r^{2}=0.773, P<0.01\right)\right]$ was observed (Fig. 2).

The allometric analysis between roots and shoots showed that BAP application increased dry weight partitioning to shoots, as revealed by lower values of the coefficient $\beta$. Within shoots,
BAP sprays tended to increase partitioning towards the stem-petiole fraction (Table 3).

There were no significant changes in chlorophyll content per unit leaf area or dry weight, except for a decrease found with three BAP applications when chlorophyll content was expressed on a dry weight basis (Table 4).

\subsection{BAP and Light Integral Relationships}

The response to BAP sprays was evaluated under different light intensities. Whole plant dry weight accumulation was promoted by BAP under the three environments assayed (70, 50 and $30 \%$ full sunlight), but differences in optimal concentrations and magnitude of the response varied among light treatments and significant interactions (BAP concentration $x$ light intensity) were observed according to ANOVA $(P<0.001$ for stem and root, and $P<0.05$ for leaf and petiole dry weight) (data not shown). Under $70 \%$ full sunlight, the highest response was achieved with $2.5 \mathrm{mg} \mathrm{L}^{-1}$ BAP (Fig. 3a). Plants under $50 \%$ full sunlight accumulated dry weight at a substantially lower rate than under $70 \%$ full sunlight; however, the promotion of dry weight accumulation by BAP, in relation to control plants, was relatively higher than under $70 \%$ full sunlight; the highest effect was observed with $5 \mathrm{mg} \mathrm{L} \mathrm{L}^{-1}$ BAP (Fig. 3b). Under the lowest irradiance (30\% full sunlight), a low dry weight accumulation was observed in control plants and the maximum promotion of dry weight accumulation was achieved with $5 \mathrm{mg} \mathrm{L}^{-1}$ BAP (Fig. 3c).

Table 1. Monthly patterns of daily minimum and maximum temperatures and mean daily photosynthetically active radiation (PAR) integral during the three experimental seasons

\begin{tabular}{|c|c|c|c|c|c|c|c|c|c|}
\hline & \multicolumn{3}{|c|}{$\begin{array}{l}\text { Minimum temperature } \\
\left({ }^{\circ} \mathrm{C}\right)\end{array}$} & \multicolumn{3}{|c|}{$\begin{array}{c}\text { Maximum temperature } \\
\left({ }^{\circ} \mathrm{C}\right)\end{array}$} & \multicolumn{3}{|c|}{$\begin{array}{c}\text { PAR } \\
\left.\text { (mol photons } \mathrm{m}^{-2} \mathrm{~d}^{-1}\right)\end{array}$} \\
\hline & $\begin{array}{l}2006- \\
2007\end{array}$ & 2007- & $\begin{array}{l}2008- \\
2009\end{array}$ & $\begin{array}{l}2006- \\
2007\end{array}$ & $\begin{array}{l}2007- \\
2008\end{array}$ & $\begin{array}{l}2008- \\
2009\end{array}$ & $\begin{array}{l}2006- \\
2007\end{array}$ & $\begin{array}{l}2007- \\
2008\end{array}$ & $\begin{array}{l}2008- \\
2009\end{array}$ \\
\hline September & 10.28 & 12.68 & 10.48 & 20.94 & 21.38 & 18.63 & 7.61 & 6.34 & 5.93 \\
\hline October & $14.7 \varepsilon$ & 14.37 & 13.27 & 24. & 23. & & 8.94 & 8.15 & 8.78 \\
\hline & & & & & & & & & \\
\hline & 19.5 & 18. & 19. & 30. & 29 & & 10.71 & 10.99 & 10.79 \\
\hline January & 20.15 & 20.69 & 20.60 & 29.39 & 30.62 & 31.13 & 9.88 & 10.46 & 11.16 \\
\hline February & 19.72 & 20.68 & 19.3 & 30.08 & 29.90 & 29.90 & 8.36 & 8.66 & 9.74 \\
\hline March & 18.03 & 17.64 & 19.45 & 25.97 & 26.56 & 28.18 & 5.85 & 6.82 & 7.70 \\
\hline
\end{tabular}




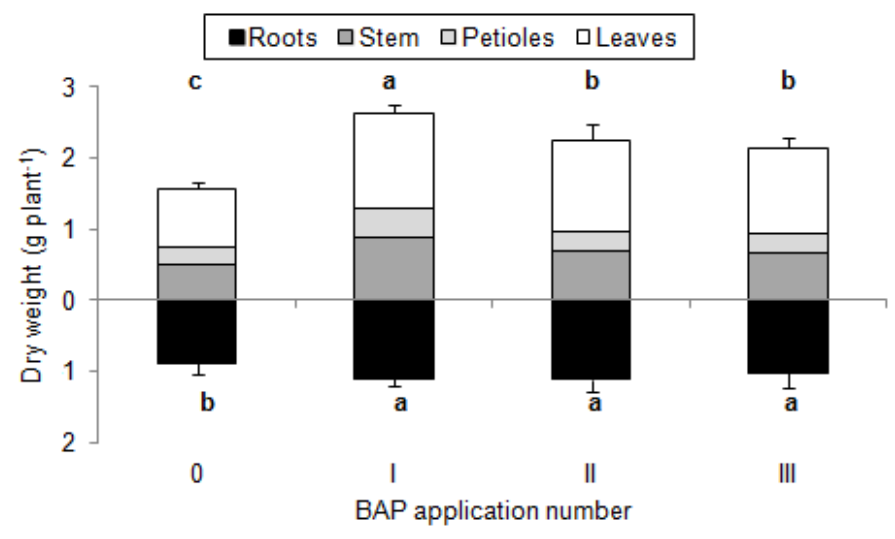

Fig. 1. Mean dry weights $(n=3)$ of different plant parts (roots, stem, petioles, and leaves) at the end of the 2007-2008 experiment in $E$. aureum plants subjected to different number of applications of $5 \mathrm{mg} \mathrm{L}^{-1}$ BAP. Bars indicate standard errors. Different letters indicate statistical significance $(P<0.05)$ for total aerial biomass and roots

Table 2. Effect of a different number of $5 \mathrm{mg} \mathrm{L}^{-1}$ BAP applications on RGR, NAR, LAR, LAP and root: shoot ratio (2007-2008 experiment). Mean values $(n=3)$ in each column followed by a different lower-case letter indicate significant differences $(P<0.05)$. The probability of the slope being zero was $P=0.001$ for all growth parameters

\begin{tabular}{|c|c|c|c|c|c|}
\hline $\begin{array}{l}\text { BAP } \\
\text { applications }\end{array}$ & $\begin{array}{l}\text { RGR } \\
\left(\mathrm{mg} \mathrm{g}^{-1} \mathrm{day}^{-1}\right)\end{array}$ & $\begin{array}{l}\text { NAR } \\
\left(\text { g cm }^{-2} \text { day }^{-1}\right) \\
\left(x 1^{-5}\right)\end{array}$ & $\begin{array}{l}\text { LAR } \\
\left(\mathrm{cm}^{2} \mathrm{~g}^{-1}\right)\end{array}$ & $\begin{array}{l}\text { LAP } \\
\frac{\left(\mathrm{cm}^{2} \text { day }^{-1}\right)}{\left(\text { g day }^{-1}\right)}\end{array}$ & $\begin{array}{l}\text { Root: } \\
\text { Shoot ratio }\end{array}$ \\
\hline 0 & $12.34^{\mathrm{C}}$ & $11.62^{\mathrm{C}}$ & $105.86^{\mathrm{a}}$ & $121.35^{\mathrm{a}}$ & $0.56^{\mathrm{a}}$ \\
\hline I & $14.67^{\mathrm{a}}$ & $14.80^{\mathrm{a}}$ & $98.68^{\mathrm{b}}$ & $104.76^{\mathrm{C}}$ & $0.42^{\mathrm{c}}$ \\
\hline II & $13.51^{\mathrm{b}}$ & $13.12^{b}$ & $102.88^{\mathrm{a}}$ & $113.55^{\mathrm{b}}$ & $0.49^{b}$ \\
\hline III & $12.98^{\mathrm{b}}$ & $11.91^{\mathrm{c}}$ & $108.29^{a}$ & $123.40^{\mathrm{a}}$ & $0.48^{\mathrm{b}}$ \\
\hline
\end{tabular}

In agreement with this, BAP sprays increased RGR under the three light environments tested, but promotion was relatively higher at the intermediate light intensity. In parallel, NAR generally increased and LAR and LAP decreased with BAP treatment (Table 5). The promotion of NAR by BAP treatment tended to be higher than that of RGR (i.e. $32.9 \%$ vs $18.6 \%$ increases in NAR and RGR, respectively, by $5 \mathrm{mg}$ $\mathrm{L}^{-1}$ BAP under $70 \%$ full sunlight). RGR of control plants decreased with a decreasing light intensity and this effect was generally accompanied by a decrease in NAR and an increase in both LAR and LAP. Furthermore, SLA and LWR increased with decreasing light intensity, while BAP sprays tended to reduce their values (Table 5).

When data from different BAP treatments and light environments were plotted together; a close direct relationship between RGR and NAR $\left(r^{2}=\right.$ $0.944, P<0.001$, Fig. 4a) was found, while a significant inverse relationship between RGR and LAR $\left(r^{2}=0.488, P<0.01\right.$, Fig. $\left.4 b\right)$ was observed. Besides, significant direct relationships between
SLA and LAR $\left(r^{2}=0.263, P<0.01\right.$, Fig. 4c) and between LWR and LAR $\left(r^{2}=0.428, P<0.01\right.$, Fig. 4d) were observed.

BAP application determined a general decrease in the allometric coefficient $\boldsymbol{\beta}$ between roots and shoots under the three light environments, although at the highest BAP concentrations under $50 \%$ full sun, differences with respect to controls were not significant (Table 6) ANOVA revealed a significant $(P<0.001) \quad$ BAP concentration $x$ light intensity interaction (not shown). The influence of BAP sprays on the allometric pattern within the aerial part was generally lower than that on root: Shoot allometry, but nevertheless significant decreases in the allometric coefficient $\boldsymbol{\beta}$ for the leaf blades vs. stems + petioles relationship were found in plants treated with BAP at low concentrations, especially under the lowest light intensities (Table 6). Again, in this case, ANOVA revealed a significant $(P<0.001)$ BAP concentration $x$ light intensity interaction (not shown). 


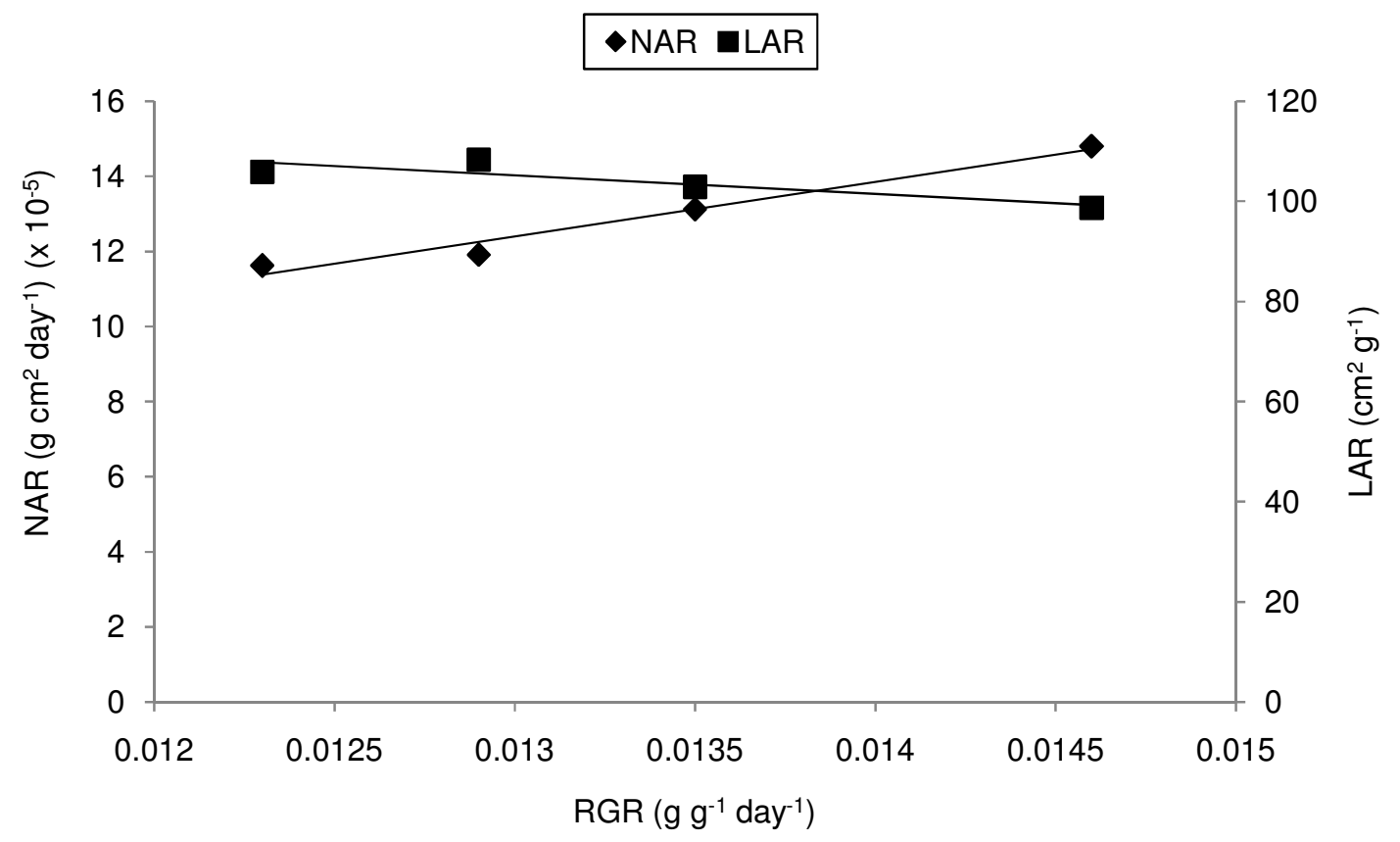

Fig. 2. Changes in the net assimilation rate (NAR) and the leaf area ratio (LAR) related to the relative growth rate (RGR). The straight-line regressions were: NAR $\times 10^{-5}=1.45$ RGR-6.46 $\left(r^{2}=\right.$ $0.972, P<0.001)$ and $L A R=-3.71 R G R+153.32\left(r^{2}=0.773, P<0.001\right)$

Table 3. Allometric relationships between shoots and roots (In Root dry weight $=\alpha+\beta \times$ In Shoot dry weight) $(n=30)$ and between leaf blades and petioles-stems (In Leaf Blades dry weight $=\alpha+\beta \times \ln$ Petioles + Stems dry weight $)(n=36)$ in $E$. aureum cuttings subjected to a different number of $5 \mathrm{mg} \mathrm{L}^{-1}$ BAP applications (2007-2008 experiment). Mean values in each column followed by a different lower-case letter indicate significant different slopes according to SMATR analysis. The probability of the slope being zero was $P<0.001$

\begin{tabular}{lllllll}
\hline $\begin{array}{l}\text { BAP } \\
\text { applications }\end{array}$ & \multicolumn{3}{c}{ Roots vs. Shoots } & \multicolumn{3}{c}{$\begin{array}{c}\text { Leaf blades vs. } \\
\text { Petioles-Stems }\end{array}$} \\
\cline { 2 - 7 } & $\boldsymbol{\alpha}$ & $\boldsymbol{\beta}$ & $\mathbf{r}^{2}$ & $\boldsymbol{\alpha}$ & $\boldsymbol{\beta}$ & $\mathbf{r}^{2}$ \\
\hline 0 & -0.57 & $0.79^{\mathrm{a}}$ & 0.74 & 0.40 & $1.17^{\mathrm{a}}$ & 0.87 \\
I & -0.36 & $0.54^{\mathrm{b}}$ & 0.66 & 0.22 & $1.11^{\mathrm{b}}$ & 0.99 \\
II & -0.64 & $0.57^{\mathrm{b}}$ & 0.61 & 0.18 & $1.10^{\mathrm{b}}$ & 0.98 \\
III & -0.56 & $0.48^{\mathrm{c}}$ & 0.73 & 0.41 & $1.17^{\mathrm{a}}$ & 0.96 \\
\hline
\end{tabular}

Table 4. Effect of a different number of $5 \mathrm{mg} \mathrm{L}^{-1}$ BAP applications on chlorophyll content of $E$. aureum leaves at final harvest (2007-2008 experiment). Mean values $(n=3)$ in each column followed by a different lower-case letter indicate significant differences at $P<0.05$

\begin{tabular}{llr}
\hline BAP applications & \multicolumn{2}{c}{ Chlorophyll content } \\
\cline { 2 - 3 } & $\left(\mu \mathbf{~ c m}^{2}\right)$ & $\left(\mathbf{m g ~ g}^{-1} \mathbf{d r y}\right.$ weight $)$ \\
\hline 0 & $33.5^{\mathrm{a}}$ & $12.78^{\mathrm{a}}$ \\
I & $36.2^{\mathrm{a}}$ & $12.94^{\mathrm{a}}$ \\
II & $38.1^{\mathrm{a}}$ & $12.99^{\mathrm{a}}$ \\
III & $27.0^{\mathrm{a}}$ & $9.60^{\mathrm{b}}$ \\
\hline
\end{tabular}


Chlorophyll concentration per unit dry weight was not significantly affected by BAP application, except for minor variation observed under the lowest irradiance. However, when expressed per unit leaf area, chlorophyll content generally increased in BAP-treated plants (especially with low BAP concentrations) with respect to controls (Table 6). This effect may be attributed to the BAP-driven moderate decrease in SLA, shown in Table 4. Besides, chlorophyll concentration tended to increase with a decreasing irradiance (Table 7).

Nitrogen concentration (mg N dry weight ${ }^{-1}$ ) was slightly (about 7\%) but significantly increased by $5 \mathrm{mg} \mathrm{L}^{-1}$ BAP treatment, under the three irradiances tested. When expressed on a leaf area basis this effect was even more pronounced $(20-25 \%)$ (Table 8$)$, which is again attributable to a decrease in specific leaf area of BAP-treated plants.

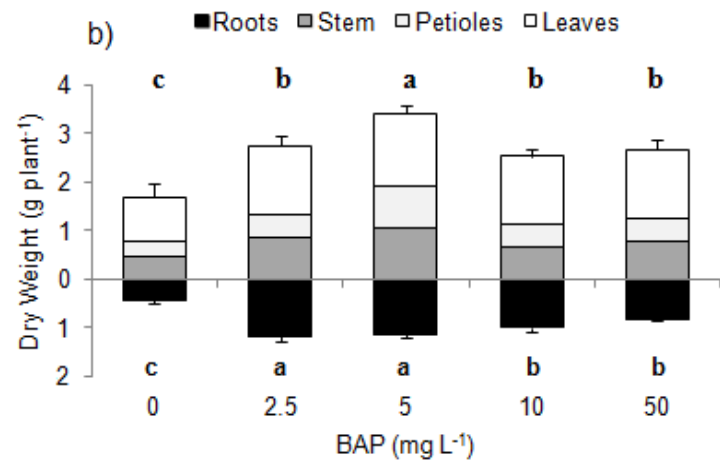

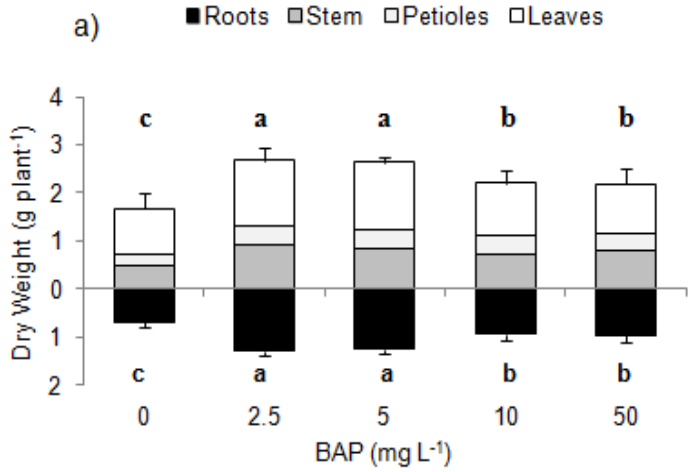

c)
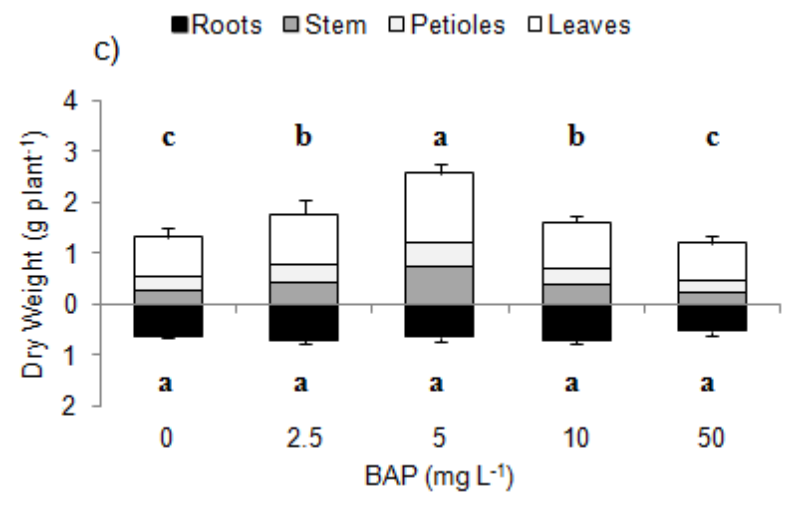

\begin{tabular}{|c|c|c|c|c|}
\hline ANOVA & & & & \\
\hline Source of variation & & & & \\
\hline & Leaves & Petioles & Stems & Roots \\
\hline BAP concentration & 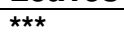 & $\star \star \star *$ & $\star \star \star$ & 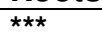 \\
\hline Light intensity & ** & ** & $\star \star \star \star ~$ & $\star \star \star *$ \\
\hline BAP concentration $x$ Light Intensity & ** & ** & $* * *$ & $* \star *$ \\
\hline
\end{tabular}

Fig. 3. Mean dry weight $(n=3)$ from different plant parts (roots, stem, petioles and leaves) at the end of the 2008-2009 experiment in E. aureum plants grown under three light environments: $70 \%$ (a), $50 \%$ (b) and $30 \%$ (c) full sunlight and sprayed with different BAP concentrations. The standard errors over each bar and the significance of interactions (ANOVA) have been indicated. Different letters indicate statistical significance $(P<0.05)$ based on total aerial biomass and roots 


\section{DISCUSSION}

Ornamental plants like E. aureum are commonly grown in pots for commercial purposes. Under these conditions, roots are impeded to develop normally [28] and this restriction would be associated with a limited production of cytokinins [29] which in turn negatively affects the development of the aerial part [11]. In a previous paper [3] we showed that this effect can be reverted by exogenous cytokinin supply and that a single spray of $5 \mathrm{mg} \mathrm{L}^{-1}$ BAP on $E$. aureum potted plants promoted leaf area and fresh weight accumulation. In the present work we show that BAP also increased RGR, which in turn depended on a number of applications (Table 2), BAP concentration and light environment (Table 5).

To investigate whether the BAP-driven increase in RGR could be explained either by an increased resource investment in the development of leaf area or by an increased efficiency of dry weight fixation per unit leaf area, a classic growth analysis approach was used. Apriori, both alternatives appeared as likely since there is abundant experimental or bibliographic support: In our previous paper [3] it was shown that BAP increased $E$. aureum final leaf size and decreased the phyllochron, but cytokinins are also well known to promote the efficiency of the photosynthetic apparatus [30].

RGR is the product of LAR, the so-called 'morphological component' and NAR, the 'physiological component'. A change in dry weight partitioning towards the development of leaf area would be reflected in an increased LAR, while an increased efficiency of dry weight fixation would be associated with higher NAR values, since this variable is largely the net result of dry weight gain and dry weight losses [31]. In our experiments one single application of $5 \mathrm{mg} \mathrm{L}^{-1}$ BAP led to an average increase in RGR of $19.4 \%$ and $18.7 \%$ in the 2007-2008 and 2008-2009 experiments respectively and this effect was associated with an increase in NAR of $35.6 \%$ and $27.3 \%$ with a relatively slight decrease in LAR of $12.0 \%$ and $13.7 \%$ respectively (Tables 2 and $5-70 \%$ full sunlight). This negative effect of BAP spray on LAR was somewhat unexpected, since treated plants developed larger leaves and also more leaves per unit time [3] and also promoted lower root: Shoot ratios. Moreover, a close direct relationship between RGR and NAR
(Figs. 3 and $4 a$ ) could be observed plotting data from all treatments of Tables 2 and 5 while an inverse relationship was found between RGR and LAR (Figs. 3 and $4 \mathrm{~b}$ ). Thus, BAP sprays enhanced NAR even more than RGR. On the other hand, the BAP-induced decrease in LAR could be attributed mainly to lower LWR (which measures the allocation of biomass to leaves vs. other plant parts) [31] in treated plants, but also to changes in SLA (Fig. 4d).

The strong BAP-mediated increase in NAR could be the consequence of different possible effects of cytokinin on the efficiency of carbon fixation. Cytokinins have long been implicated in chlorophyll synthesis [30] although this not always results in an increased concentration in plant tissues [32]. In our experiments, chlorophyll concentration per unit dry weight was unaffected by BAP treatment. Cytokinins also appear to increase nitrogen content in plants $[33,34]$ and in accordance with this, an increased leaf nitrogen concentration per unit dry weight was found as a consequence of $5 \mathrm{mg} \mathrm{L}^{-1}$ BAP treatment (Table 8). Although we have not attempted to determine whether or not part of the increased nitrogen concentration corresponds to enzymes involved in carbon fixation, this possibility seems likely, since cytokinins have been reported to promote synthesis of Rubisco [35]. Furthermore, BAP might promote leaf blade thickening, thus leading to an increase in the levels of photosynthetic machinery per unit leaf area [36]. SLA reflects biomass per unit leaf area and is well correlated to leaf thickness [37]. Changes in SLA as a consequence of BAP treatment were relatively small, however a decreasing trend was observed, which reflects a moderate leaf thickening (Table 5) and this contributed to a slight increase in chlorophyll and especially in nitrogen content per unit leaf area. Therefore, it seems likely that NAR promotion by BAP is related to an increased efficiency of carbon fixation per unit leaf area, similarly as reported for tobacco by Werner et al. [38].

To further explain the observed decrease in LAR in BAP-treated plants, the relationship between leaf development and dry weight partitioning was analyzed. First, values of the LAP coefficient, a parameter which was originally proposed to evaluate dry weight investment on the development of leaf area [18] decreased as a consequence of BAP treatment (Tables 2 and 5). 
Table 5. Effect of a single BAP spray at different concentrations on RGR, NAR, LAR, LAP, SLA, LWR and root: shoot ratio of $E$. aureum plants grown under different light intensities $(70 \%, 50 \%$ and $30 \%$ full sunlight) $(2008-2009$ experiment). Mean values ( $n=3)$. Different lower-case letters indicate significant differences $(P<0.05)$ between BAP concentrations while different capital letters indicate significant differences $(P=0.05)$ for each BAP concentration between different light intensities. The probability of the slope being zero was $P=0.001$ for all growth parameters

\begin{tabular}{|c|c|c|c|c|c|c|c|c|}
\hline $\begin{array}{l}\text { Light } \\
\text { Intensity }\end{array}$ & $\begin{array}{l}\text { BAP } \\
\left(\mathrm{mg} \mathrm{L}^{-1}\right)\end{array}$ & $\begin{array}{l}\text { RGR } \\
\left(\mathrm{mg} \mathrm{g}^{-1} \mathrm{day}^{-1}\right)\end{array}$ & $\begin{array}{l}\text { NAR } \\
\left(\text { g cm }^{-2} \text { day }^{-1}\right) \\
\left(\times 10^{-5}\right)\end{array}$ & $\begin{array}{l}\text { LAR } \\
\left(\mathrm{cm}^{2} \mathrm{~g}^{-1}\right)\end{array}$ & $\begin{array}{l}\text { LAP } \\
\frac{\left(\mathrm{cm}^{2} \mathrm{day}^{-1}\right)}{\left(\mathrm{g} \mathrm{day}^{-1}\right)}\end{array}$ & $\begin{array}{l}\text { SLA } \\
\left(\mathrm{cm}^{2} \mathrm{~g}^{-1}\right)\end{array}$ & $\begin{array}{l}\text { LWR } \\
\left.\left(g^{-1}\right)^{-1}\right)\end{array}$ & $\begin{array}{l}\text { Root: } \\
\text { Shoot ratio }\end{array}$ \\
\hline \multirow[t]{5}{*}{$70 \%$ full sun } & 0 & $12.35^{\mathrm{CA}}$ & $10.96^{\mathrm{CA}}$ & $112.27^{\mathrm{aA}}$ & $131.44^{\mathrm{ac}}$ & $336.37^{\mathrm{aB}}$ & $0.37^{\mathrm{bC}}$ & $0.43^{\mathrm{ab}}$ \\
\hline & 2.5 & $14.61^{\mathrm{aA}}$ & $13.59^{\mathrm{aA}}$ & $104.49^{\mathrm{bB}}$ & $114.79^{\mathrm{bB}}$ & $333.31^{\mathrm{aB}}$ & $0.36^{\mathrm{bB}}$ & $0.41^{\mathrm{aA}}$ \\
\hline & 5 & $14.65^{\mathrm{aA}}$ & $14.57^{\mathrm{aA}}$ & $100.23^{\mathrm{bc}}$ & $107.79^{\mathrm{bc}}$ & $299.83^{\mathrm{bB}}$ & $0.34^{\mathrm{bc}}$ & $0.41^{\mathrm{aA}}$ \\
\hline & 10 & $13.10^{\mathrm{bA}}$ & $12.47^{\mathrm{bA}}$ & $105.10^{\mathrm{bB}}$ & $117.13^{\mathrm{bc}}$ & $290.19^{\mathrm{bB}}$ & $0.43^{\mathrm{aA}}$ & $0.43^{\mathrm{aA}}$ \\
\hline & 50 & $13.32^{\mathrm{bA}}$ & $11.98^{\mathrm{bA}}$ & $111.06^{\mathrm{aB}}$ & $127.76^{\mathrm{aC}}$ & $274.89^{\mathrm{bB}}$ & $0.43^{\mathrm{aA}}$ & $0.40^{\mathrm{aA}}$ \\
\hline \multirow[t]{5}{*}{$50 \%$ full sun } & 0 & $9.36^{\mathrm{CB}}$ & $7.78^{\mathrm{CB}}$ & $119.49^{\mathrm{aA}}$ & $154.18^{\mathrm{aB}}$ & $371.97^{\mathrm{aA}}$ & $0.48^{\mathrm{aA}}$ & $0.43^{\mathrm{aB}}$ \\
\hline & 2.5 & $13.50^{\mathrm{aB}}$ & $12.69^{\mathrm{aB}}$ & $106.36^{\mathrm{bB}}$ & $115.81^{\mathrm{CB}}$ & $327.38^{\mathrm{bB}}$ & $0.39^{\mathrm{bB}}$ & $0.35^{\mathrm{bB}}$ \\
\hline & 5 & $14.65^{\mathrm{aA}}$ & $12.74^{\mathrm{aB}}$ & $114.57^{\mathrm{aB}}$ & $132.62^{\mathrm{bB}}$ & $318.32^{\mathrm{bA}}$ & $0.47^{\mathrm{bA}}$ & $0.33^{\mathrm{bB}}$ \\
\hline & 10 & $12.28^{\mathrm{bB}}$ & $11.02^{\mathrm{bB}}$ & $110.75^{\mathrm{aB}}$ & $128.00^{\mathrm{bB}}$ & $316.09^{\mathrm{bA}}$ & $0.39^{\mathrm{cB}}$ & $0.34^{\mathrm{bB}}$ \\
\hline & 50 & $14,50^{\mathrm{aA}}$ & $12.53^{\mathrm{aA}}$ & $115.71^{\mathrm{aB}}$ & $134.07^{\mathrm{bB}}$ & $338.18^{\mathrm{bA}}$ & $0.43^{\mathrm{bA}}$ & $0.31^{\mathrm{bB}}$ \\
\hline \multirow[t]{5}{*}{$30 \%$ full sun } & 0 & $7.82^{\mathrm{cC}}$ & $6.38^{\mathrm{dc}}$ & $122.17^{\mathrm{aA}}$ & $170.72^{\mathrm{aA}}$ & $373.53^{\mathrm{aA}}$ & $0.46^{\mathrm{ab}}$ & $0.49^{\mathrm{aA}}$ \\
\hline & 2.5 & $11.79^{\mathrm{aC}}$ & $9.97^{\mathrm{aC}}$ & $118.34^{\mathrm{aA}}$ & $145.42^{\mathrm{bA}}$ & $357.98^{\mathrm{aA}}$ & $0.43^{\mathrm{aA}}$ & $0.40^{\mathrm{bA}}$ \\
\hline & 5 & $11.86^{\mathrm{aB}}$ & $9.18^{\mathrm{bc}}$ & $124.14^{\mathrm{aA}}$ & $158.98^{\mathrm{bA}}$ & $329.11^{\mathrm{bA}}$ & $0.40^{\mathrm{bB}}$ & $0.40^{\mathrm{bA}}$ \\
\hline & 10 & $10.88^{\mathrm{aC}}$ & $8.92^{\mathrm{bC}}$ & $114.38^{\mathrm{aA}}$ & $144.65^{\mathrm{bA}}$ & $315.39^{\mathrm{bA}}$ & $0.41^{\mathrm{bB}}$ & $0.38^{\mathrm{bB}}$ \\
\hline & 50 & $10.11^{\mathrm{bB}}$ & $8.29^{\mathrm{cB}}$ & $120.59^{\mathrm{aA}}$ & $156.77^{\mathrm{bA}}$ & $343.76^{\mathrm{bA}}$ & $0.43^{\mathrm{bA}}$ & $0.41^{\mathrm{bA}}$ \\
\hline
\end{tabular}


a)

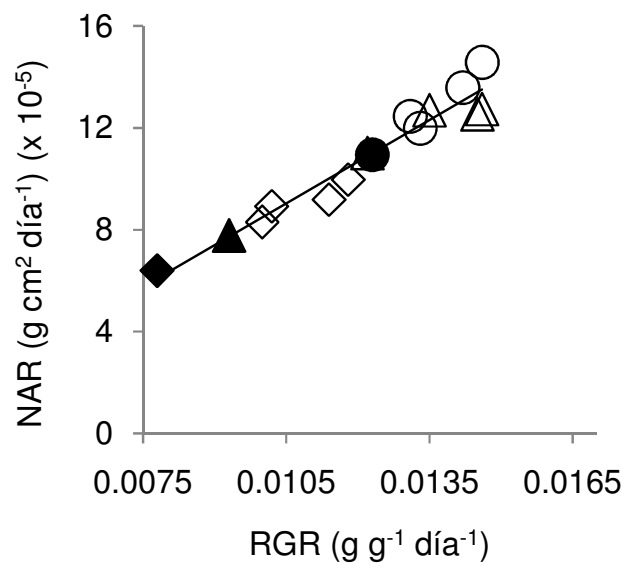

c)

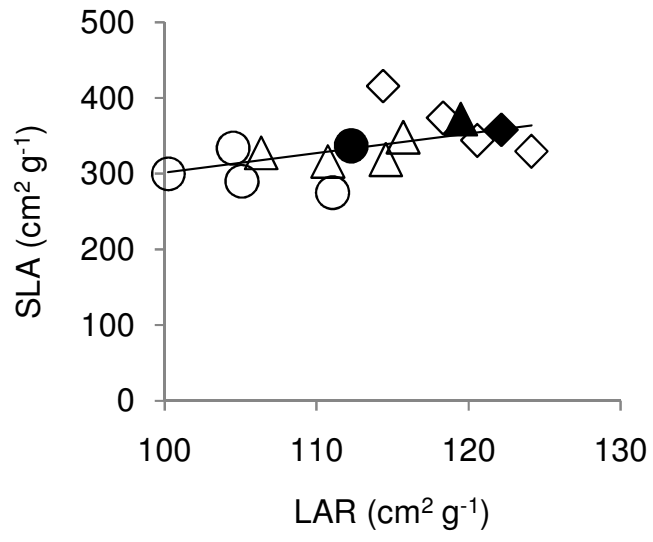

b)

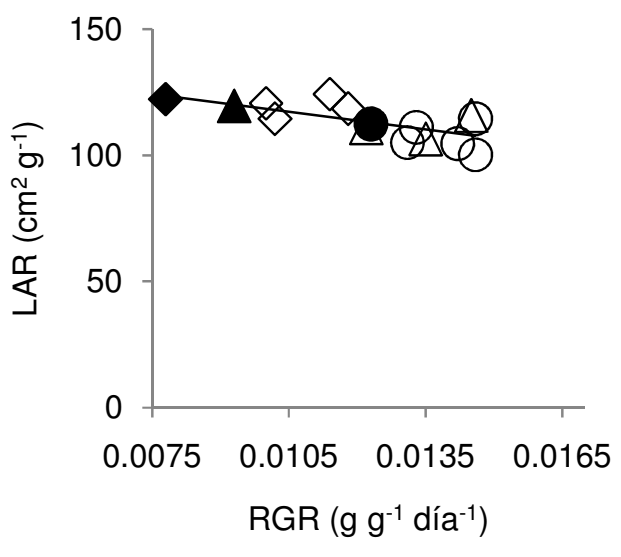

d)

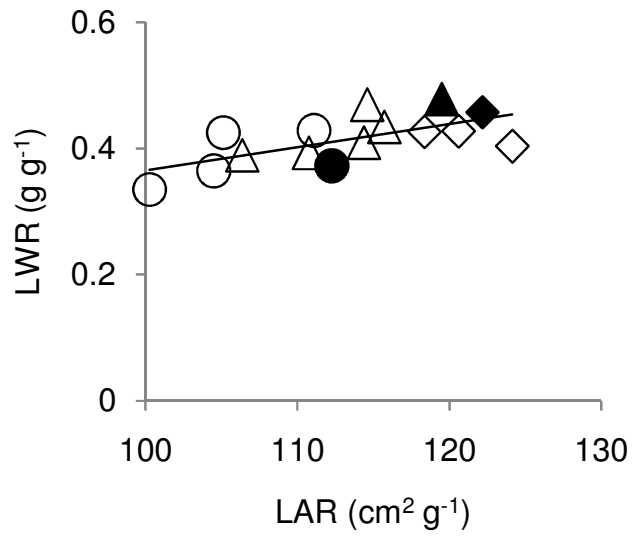

Fig. 4. Relationships between NAR $\left(\mathrm{gcm}^{-2}\right.$ day $\left.^{-1} \times 10^{-5}\right)$ (A), LAR $\left(\mathrm{cm}^{2} \mathrm{~g}^{-1}\right)$ (B) and RGR $\left(\mathrm{mg} \mathrm{g}^{-1}\right.$ day $\left.^{-1}\right)$ and between SLA $\left(\mathrm{cm}^{2} \mathrm{~g}^{-1}\right)(\mathrm{C})$ or LWR $\left(\mathrm{g} \mathrm{g}^{-1}\right)(D)$ and LAR $(\mathrm{n}=3)$. Linear regression equations are: NAR $\times 10^{-5}=1.092$ RGR $-2.43\left(r^{2}=0.944, P<0.001\right)$; LAR $=-2.34 R G R+141.88$ $\left(r^{2}=0.488, P<0.01\right) ;$ SLA = 2.58 LAR + 43.53 $\left(r^{2}=0.363, P<0.01\right) ;$ LWR $=0.0037$ LAR + $0.0003\left(r^{2}\right.$ $=0.428, P<0.01) . \bullet, \circ: 70 \% ; \triangle, \Delta: 50 \%$ and $\downarrow, \diamond: 30 \%$ full sun. Controls: close symbols; BAPsprayed: open symbols

Second, an analysis of the allometric ratios between roots and shoots and between leaves and stems + petioles was carried out. We have analyzed stems and petioles together because both tissues derive from the same group of cell at the apex [39]. Changes in the allometric ratios reflect variation in dry weight partitioning [40], and partitioning of resources between competing sites is fundamental to plant growth; especially because plants are capable of modifying their resource allocation to favor the development of their growing parts [41]. This analysis showed that BAP applications, at least at the concentrations that are most effective in promoting growth, led to an increase in partitioning towards the aerial part but that, within the latter, BAP increased the partitioning towards stem and petioles rather than to leaf blades (Tables 3 and 6). This is presumably associated with thicker stems in BAP-sprayed plants and in turn it could be related to the promoting effect of BAP on the rate of leaf appearance in E. aureum, which was reported in a previous paper [3]. It has been suggested that cytokinins control growth mainly through the regulation of cell division and differentiation in the stem apical meristem [42] and that the size of the apical meristem is in turn related to the rate of leaf appearance, as shown in experiments with cytokinin deficient Arabidopsis mutants [16]. 
Table 6. Allometric relationships between roots and shoots (In Root dry weight $=\alpha+\beta \times$ In Shoot dry weight) $(n=30)$ and between leaf blades and petioles-stems (In Leaf Blades dry weight $=\alpha+\beta \times$ In Petioles + Stems dry weight) $(n=36)$ in $E$. aureum plants grown under $70 \%$, $50 \%$ or $30 \%$ full sunlight and sprayed with BAP at different concentrations (2008-2009 experiment). Mean values in each column followed by a different lower-case letter indicate significantly different slopes between BAP concentrations while different capital letters indicate significant differences $(P<0.05)$ for each BAP concentration between different light intensities according to SMATR analysis

\begin{tabular}{|c|c|c|c|c|c|c|c|}
\hline \multirow[t]{2}{*}{$\begin{array}{l}\text { Light } \\
\text { Intensity }\end{array}$} & \multirow[t]{2}{*}{$\begin{array}{l}\text { BAP } \\
\left(\mathrm{mg} \mathrm{L}^{-1}\right)\end{array}$} & \multicolumn{3}{|c|}{ Roots vs. Shoots } & \multicolumn{3}{|c|}{$\begin{array}{l}\text { Leaf blades vs. } \\
\text { Petioles-Stems }\end{array}$} \\
\hline & & $\alpha$ & $\beta$ & $r^{2}$ & $\alpha$ & $\beta$ & $r^{2}$ \\
\hline \multirow{5}{*}{$70 \%$ full sun } & 0 & -0.57 & $0.79^{\mathrm{ac}}$ & 0.74 & 0.17 & $1.00^{\mathrm{bC}}$ & 0.98 \\
\hline & 2.5 & -0.46 & $0.64^{\mathrm{bB}}$ & 0.65 & 0.06 & $0.95^{\mathrm{cC}}$ & 0.99 \\
\hline & 5 & -0.44 & $0.50^{\mathrm{cB}}$ & 0.69 & 0.07 & $1.02^{\mathrm{bA}}$ & 0.95 \\
\hline & 10 & -0.57 & $0.58^{\mathrm{bC}}$ & 0.60 & 0.12 & $1.04^{\mathrm{aA}}$ & 0.99 \\
\hline & 50 & -0.66 & $0.59^{\mathrm{bB}}$ & 0.64 & 0.16 & $1.04^{\mathrm{aB}}$ & 0.99 \\
\hline \multirow[t]{5}{*}{$50 \%$ full sun } & 0 & -1.08 & $0.80^{\mathrm{aB}}$ & 0.64 & 0.36 & $1.12^{\mathrm{aB}}$ & 0.95 \\
\hline & 2.5 & -0.64 & $0.61^{\mathrm{bB}}$ & 0.72 & 0.13 & $1.04^{\mathrm{bB}}$ & 0.99 \\
\hline & 5 & -1.12 & $0.62^{\mathrm{bA}}$ & 0.73 & 0.08 & $0.94^{\mathrm{cA}}$ & 0.98 \\
\hline & 10 & -0.72 & $0.76^{\mathrm{aA}}$ & 0.61 & 0.17 & $1.07^{\mathrm{bA}}$ & 0.99 \\
\hline & 50 & -0.90 & $0.77^{\mathrm{aA}}$ & 0.77 & 0.09 & $0.98^{\mathrm{bB}}$ & 0.99 \\
\hline \multirow[t]{5}{*}{$30 \%$ full sun } & 0 & -0.94 & $0.95^{\mathrm{aA}}$ & 0.67 & 0.71 & $1.38^{\mathrm{aA}}$ & 0.96 \\
\hline & 2.5 & -0.97 & $0.80^{\mathrm{bA}}$ & 0.77 & 0.28 & $1.15^{\mathrm{cA}}$ & 0.99 \\
\hline & 5 & -0.89 & $0.57^{\mathrm{cA}}$ & 0.61 & 0.13 & $1.01^{\mathrm{dA}}$ & 0.98 \\
\hline & 10 & -0.93 & $0.67^{\mathrm{cB}}$ & 0.64 & 0.16 & $1.08^{\mathrm{dA}}$ & 0.99 \\
\hline & 50 & -0.85 & $0.49^{\mathrm{dC}}$ & 0.63 & 0.45 & $1.22^{\mathrm{bA}}$ & 0.97 \\
\hline
\end{tabular}

Table 7. Effect of a single BAP spray at different concentrations on chlorophyll content in

E. aureum leaves at final harvest in plants grown under different light intensities $\mathbf{7 0} \%, 50 \%$ and $30 \%$ full sunlight) $(2008-2009$ experiment). Mean values $(n=3)$ followed by different lowercase letters indicate significant differences between BAP concentrations while different capital letters indicate significantly differences for each BAP concentration between different light intensities $(P<0.05)$

\begin{tabular}{lllr}
\hline Light Intensity & BAP & & Chlorophyll content \\
\hline & $\left(\mathbf{m g ~ L}^{-1}\right)$ & $\left(\boldsymbol{\mu g} \mathbf{~ c m}^{-2}\right)$ & $\left(\mathbf{m g ~ g}^{-1} \mathbf{d r y}\right.$ weight $)$ \\
\hline $70 \%$ full sun & 0 & $33.5^{\mathrm{bA}}$ & $11.28^{\mathrm{aB}}$ \\
& 2.5 & $37.8^{\mathrm{aA}}$ & $12.60^{\mathrm{aB}}$ \\
$50 \%$ full sun & 5 & $36 .^{\mathrm{aA}}$ & $10.86^{\mathrm{aB}}$ \\
& 10 & $35.7^{\mathrm{aA}}$ & $10.37^{\mathrm{aB}}$ \\
& 50 & $37.1^{\mathrm{aA}}$ & $10.21^{\mathrm{aB}}$ \\
& 0 & $33.2^{\mathrm{DA}}$ & $12.36^{\mathrm{ab}}$ \\
$30 \%$ full sun & 2.5 & $37.2^{\mathrm{aA}}$ & $12.19^{\mathrm{aB}}$ \\
& 5 & $37.4^{\mathrm{aA}}$ & $11.90^{\mathrm{aB}}$ \\
& 10 & $33.1^{\mathrm{bA}}$ & $10.47^{\mathrm{aB}}$ \\
& 50 & $37.2^{\mathrm{aA}}$ & $12.94^{\mathrm{aA}}$ \\
& 0 & $36.7^{\mathrm{DA}}$ & $13.14^{\mathrm{DA}}$ \\
& 2.5 & $39.6^{\mathrm{aA}}$ & $14.80^{\mathrm{aA}}$ \\
& 5 & $38.9^{\mathrm{aA}}$ & $12.81^{\mathrm{bA}}$ \\
& 10 & $37.3^{\mathrm{bA}}$ & $15.48^{\mathrm{aA}}$ \\
& 50 & $39.0^{\mathrm{aA}}$ & $13.42^{\mathrm{bA}}$ \\
\hline
\end{tabular}


Table 8. Effect of a single $5 \mathrm{mg} \mathrm{L}^{-1}$ BAP spray on nitrogen content at the final sampling in young, fully expanded leaves of $E$. aureum grown under $70 \%, 50 \%$ or $30 \%$ full sunlight (20082009 experiment). Mean values $(n=3)$ followed by different lower-case letters indicate significant differences between BAP concentrations while different capital letters indicate significant differences for each BAP concentration between different light intensities $(P<0.05)$

\begin{tabular}{|c|c|c|c|}
\hline \multirow[t]{2}{*}{ Light Intensity } & \multirow{2}{*}{$\begin{array}{l}\text { BAP } \\
\left(\mathrm{mg} \mathrm{L}^{-1}\right)\end{array}$} & \multicolumn{2}{|r|}{ Nitrogen content } \\
\hline & & $\left(\mathrm{mg} \mathrm{N} \mathrm{cm}^{-2}\right)$ & (mg N g ${ }^{-1}$ dry weight) \\
\hline $70 \%$ full sun & 0 & $0.0654^{\mathrm{DA}}$ & $21.8^{\mathrm{bA}}$ \\
\hline & 5 & $0.0784^{\mathrm{aA}}$ & $23.3^{\mathrm{aA}}$ \\
\hline $50 \%$ full sun & 0 & $0.0587^{\mathrm{bB}}$ & $20.7^{\mathrm{bB}}$ \\
\hline & 5 & $0.0684^{\mathrm{aB}}$ & $22.5^{\mathrm{aB}}$ \\
\hline $30 \%$ full sun & 0 & $0.0538^{b c}$ & $19.7^{\mathrm{bC}}$ \\
\hline & 5 & $0.0675^{\mathrm{aC}}$ & $21.7^{\mathrm{aC}}$ \\
\hline
\end{tabular}

BAP was generally most effective at a low number of applications (2007-2008 experiment) and at low concentrations (2008-2009 experiment). It is well known that plant hormones may promote a given physiological process at low concentrations but the response eventually reaches a plateau and even an inhibition may be found at higher doses. In our experiments, the fact that higher BAP concentrations or a number of applications resulted in a lower growth promotion might be the consequence of a limitation in resources availability to sustain an increased partitioning towards shoots, which was shown to be a part of the BAP response.

As expected, RGR and NAR generally decreased with shading in either control or BAPtreated plants. On the other hand, LAR tended to increase with a decreasing light intensity (Table 5 ); the latter is a common response of plants growing in poorly illuminated environments, which may be regarded as an adaptive response aimed at maximizing light capture [43]. Applying BAP increased RGR irrespective of the light environment (Table 5) as a consequence of a strong increase in NAR while LAR tended to decrease. In fact, BAP effects on NAR and LAR resembled those observed with an increased illumination in untreated plants, thus suggesting that both light and BAP may act additively, by affecting the same physiological pathway [43]. Thus, when NAR and LAR data from the 20082009 experiment were plotted as a function of RGR (Figs. 3, 4a and 4b), all data points were aligned within single linear functions for either NAR or LAR; this is, irrespective of light environment and BAP concentration. The possible additive effect of cytokinins and light are in agreement with the fact that low light intensities decrease root branching [44] and that root apices are the main source of cytokinins to the aerial part [45]. This is also in agreement with the fact that both light and BAP seemed to act additively on leaf nitrogen content (Table 8).

\section{CONCLUSION}

The results of the present work provide evidence about the mechanisms involved in the growthpromoting role of an exogenously applied cytokinin in $E$. aureum. In general, BAP applications to the aerial part of this species mimicked the reported effects of cytokinins produced naturally by the roots, including higher rates of leaf area production and dry weight accumulation, especially when supplied in low doses (one single application at a low concentration) and under non severe shading. Besides promoting higher RGR, BAP increased dry weight partitioning to shoots, but despite this, the leaf area ratio tended to decrease in treated plants. This could be partly explained because within shoots, dry matter was preferentially allocated to stems rather than to leaves. This was further confirmed by the BAP-induced decrease in the leaf area partitioning coefficient. A strong promotion of the net assimilation rate by BAP was observed, that resulted in RGR promotion despite the decrease in LAR and that could be associated with an increased $\mathrm{N}$ content per unit leaf area. Further research on other species is needed to evaluate whether these are general responses of plants to cytokinins and to analyze the physiological mechanisms underlying direct effects of cytokinins on dry weight assimilation. Finally, our results on the ornamental shade plant $E$. aureum also provide information which may help to increase productivity of this crop from a grower perspective.

\section{ACKNOWLEDGEMENTS}

This work is part of a Ph. D. thesis by A. H. Di Benedetto at the Universidad Nacional de Cuyo, 
Mendoza, Argentina. Supported by the University of Buenos Aires Science Programme 2008-2011 (Grant No. G054) and University of Mar del Plata 2008-2010 Science Programme (Grant Nos. AGR 259/08 and AGR 287/09).

\section{COMPETING INTERESTS}

Authors have declared that no competing interests exist.

\section{REFERENCES}

1. Di Benedetto A, Molinari J, Boschi C, Benedicto D, Cerrotta M, Cerrotta G. Estimating crop productivity for three ornamental foliage plants. Int. J. Agric. Res. 2006;1(6):522-533.

2. Di Benedetto A, Tognetti J, Galmarini C. Biomass production in ornamental foliage plants: Crop productivity and mechanisms associated to exogenous cytokinin supply. The Amer. J. Plant Sci. Biotech. 2010;4(1):1-22.

3. Di Benedetto A, Galmarini C, Tognetti J. Changes in leaf size and in the rate of leaf production contribute to cytokinin-mediated growth promotion in Epipremnum aureum L. cuttings. J. Hort. Sci. Biotech. 2013;88(2):179-186.

4. Wilson JW. Effects of seasonal variation in radiation and temperature on net assimilation and growth rates in an arid climate. Ann. Bot. 1967;31(1):41-57.

5. Patterson DT, Meyer CR, Quimby PC. Effects of irradiance on relative growth rates, net assimilation rates and leaf area partitioning in cotton and three associated weeds. Plant Physiol. 1978;62(1):14-17.

6. Poorter H, Remkes C, Lambers H. Carbon and nitrogen economy of 24 wild species differing in relative growth rate. Plant Physiol. 1990;94(2):621-627.

7. Shipley B. Trade-offs between net assimilation rate and specific leaf area in determining relative growth rate: The relationship with daily irradiance. Funct. Ecol. 2002;16(5):682-689.

8. Villar R, Marañón T, Quero JL, Panadero $P$, Arenas $F$, Lambers $H$. Variation in relative growth rate of 20 Aegilops species (Poaceae) in the field: The importance of net assimilation rate or specific leaf area depends on the time scale. Plant Soil. 2005;272(1-2):11-27.
9. Mc David CR, Sagar GR, Marshall C. The effect of root pruning and 6-benzylaminopurine on the chlorophyll content, 14co2 fixation and the shoot/root ratio in seedlings of Pisum sativum L. New Phytol. 1973;72(3):465-470.

10. Boonman A, Prinsen E, Gilmer F, Schurr U, Peeters AJM, Voesenek LACJ, Pons TL. Cytokinin import rate as a signal for photosynthetic acclimation to canopy light gradients. Plant Physiol. 2007;143(4):1841-1852.

11. Kyozuka J. Control of shoot and root meristem function by cytokinin. Curr. Opin. Plant Biol. 2007;10(5):442-446.

12. Albacete A, Ghanem ME, MartínezAndújar C, Acosta M, Sánchez-Bravo J, Martínez V, Lutts S, Dodd IC, PérezAlfocea F. Hormonal changes in relation to biomass partitioning and shoot growth impairment in salinized tomato (Solanum lycopersicum L.) plants. J. Exp. Bot. 2008;59(15):4119-4131.

13. Gordon SP, Chickarmane VS, Ohno C, Meyerowitz EM. Multiple feedback loops through cytokinin signaling control stem cell number within the Arabidopsis shoot meristem. Proc. Natl. Acad. Sci. USA. 2009;106(38):16529-16534.

14. Di Benedetto A, Pagani A. Dry weight accumulation in the Impatiens walleriana pot plant in responses to different pretransplant plug cell volume. Eur. J. Hort. Sci. 2013;78(2):76-85.

15. De Lojo J, Di Benedetto A. Biomass accumulation and leaf shape can be modulated by an exogenous spray of 6 benzylaminopurine in the ornamental foliage plant Monstera deliciosa (Liebm). J. Hortic. Sci. Biotech. 2014;89(2):136-140.

16. Francis D, Halford NG. Nutrient sensing in plant meristems. Plant Mol. Biol. 2006;60(6):981-993.

17. Bögre L, Magyar Z, López-Juez E. New clues to organ size control in plants. Genome Biol. 2008;9(7):226.

18. Potter J, Jones JW. Leaf area partitioning as an important factor in growth. Plant Physiol. 1977;59(1):10-14.

19. Wu X, Zhu Z, Li X, Zha D. Effects of cytokinin on photosynthetic gas exchange, chlorophyll fluorescence parameters and antioxidative system in seedlings of eggplant (Solanum melongena L.) under salinity stress. Acta Physiol. Plant. 2012;34(6):2105-2114. 
20. Zubo YO, Yamburenko MV, Selivankina SY, Shakirova FM, Avalbaev AM, Kudryakova NZ, Zubkova NK, Liere K, Kulaeva ON, Kusnetsov VV, Börner T. Cytokinin stimulates chloroplast transcription in detached barley leaves. Plant Physiol. 2008;148(2):1082-1093.

21. Hudson D, Guevara D, Yaish MW, Hannam C, Long N, Clarke JD, Bi YM, Rothstein SJ. GNC and CGA1 modulate chlorophyll biosynthesis and glutamate synthase (GLU1/Fd-GOGAT) expression in Arabidopsis. PLoS ONE. 2011;6(11):e26765.

22. Bosselaers JP. Cytokinin effects on leaf architecture in Phaseolus vulgaris L. J. Exp. Bot. 1983;34(8):1007-1017.

23. Rupp HM, Frank M, Werner T, Strnad M, Schmülling $T$. Increased steady state mRNA levels of the STM and KNAT1 homeobox genes in cytokinin overproducing Arabidopsis thaliana indicate a role for cytokinins in the shoot apical meristem. Plant J. 1999;18(4):557563.

24. Hosseini SM, Poustini K, Ahmadi A, Afshari RT. Effects of foliar application of BAP on source and sink strength in four six-rowed barley (Hordeum vulgare L.) cultivars. Plant Growth Reg. 2008;54(3):231-239.

25. Di Benedetto A, Klasman R, Boschi C. Use of river waste in growing media for ornamental herbaceous perennials. J. Hort. Sci. Biotech. 2004;79(1):119-124.

26. Inskeep WP, Bloom PR. Extinction coefficients of chlorophyll $a$ and $b$ in $\mathrm{N}, \mathrm{N}$ Dimethylformamide and $80 \%$ acetone. Plant Physiol. 1985;77(2):483-485.

27. Warton DI, Duursma RA, Falster DS, Taskinen S. smatr 3-an R package for estimation and inference about allometric lines. Meth. Ecol. Evol. 2012;3(3):257-259.

28. Di Benedetto A. Root restriction and posttransplant effects for bedding pot plants. In: Aquino JC. (ed.): Ornamental Plants: Types, Cultivation and Nutrition. Nova Science Publishers, Inc. NY, USA. 2011;47-79.

29. O'Hare TJ, Turnbull CGN. Root growth, cytokinin and shoot dormancy in lychee (Litchi chinensis Sonn.) Sci. Hortic. 2004;102(2):257-266.

30. Polanska L, Vicankova A, Novakova M, Malbeck J, Dobrev PI, Brzobohaty B, Vankova R, Machackova I. Altered cytokinin metabolism affects cytokinin, auxin and abscisic acid contents in leaves and chloroplasts and chloroplast ultrastructure in transgenic tobacco. J. Exp. Bot. 2007;58(3):637-649.

31. Shipley B. Net assimilation rate, specific leaf area and leaf mass ratio: Which is most closely correlated with relative growth rate? A meta-analysis. Funct. Ecol. 2006;20(4):565-574.

32. Kuraishi S. Ineffectiveness of cytokinininduced chlorophyll retention in hypostomatous leaf discs. Plant Cell Physiol. 1976;17(5):875-885.

33. Ruffel S, Krouk G, Ristova D, Shasha D, Birnbaum KD, Coruzzi GM. Nitrogen economics of root foraging: Transitive closure of the nitrate-cytokinin relay and distinct systemic signaling for $\mathrm{N}$ supply vs. demand. Proc. Nat. Acad. Sci. USA 2011;108(45):18524-18529.

34. Wojciechowska R, Kowalska I. The effect of foliar application of urea, Mo and BA on nitrate metabolism in lettuce leaves in the spring and summer-autumn seasons. Folia Hort. 2011;23(2):119-123.

35. Ookawa T, Naruoka Y, Sayama A, Hirasawa T. Cytokinin effects on Ribulose1 , 5-Bisphosphate Carboxylase/Oxygenase and nitrogen partitioning in rice during ripening. Crop Sci. 2004;44(6):2107-2115.

36. Ferjani A, Yano S, Horiguchi G, Tsukaya $\mathrm{H}$. Control of leaf morphogenesis by longand short-distance signaling: differentiation of leaves into sun or shade types and compensated cell enlargement. Plant Cell Monogr. 2008;10:47-62.

37. Milla R, Reich PB, Niinemets Ü, CastroDíez P. Environmental and developmental controls on specific leaf area are little modified by leaf allometry. Funct. Ecol. 2008;22:565-576.

38. Werner T, Holst K, Pors Y, Guivarch A, Mustroph A, Chriqui D, Grimm B, Schmülling T. Cytokinin deficiency causes distinct changes of sink and source parameters in tobacco shoots and roots. J. Exp. Bot. 2008;59(10):2659-2672.

39. Aida M, Tasaka M. Morphogenesis and patterning at the organ boundaries in the higher plant shoot apex. Plant Molec. Biol. 2006;60(6):915-928.

40. Kobe RK, lyer M, Walters MB. Optimal partitioning theory revisited: Nonstructural carbohydrates dominate root mass responses to nitrogen. Ecol. 2010;91(1):166-179.

41. Price CA, Weitz JS. Zero-sum allocational strategies determine the allometry of 
specific leaf area. Amer. J. Bot. 2010;97(11):1808-1815.

42. Jaillais $\mathrm{Y}$, Chory J. Unraveling the paradoxes of plant hormone signaling integration. Nature Struct. Molec. Biol. 2010;17(6):642-645.

43. Lau OS, Deng XW. Plant hormone signaling lightens up: Integrators of light and hormones. Curr. Opin. Plant Biol. 2010;13(5):571-577.
44. Tester M, Smith SE, Smith FA, Walker NA. Effects of photon irradiance on the growth of shoots and roots, on the rate of initiation of mycorrhizal infection and on the growth of infection units in Trifolium subterraneum L. New Phytol. 1986;103(2):375-390.

45. Doerner P. Plant meristems: Cytokininsthe alpha and omega of the meristem. Curr. Biol. 2007;17(9):R321-R323.

(C) 2015 Di Benedetto et al.; This is an Open Access article distributed under the terms of the Creative Commons Attribution License (http://creativecommons.org/licenses/by/4.0), which permits unrestricted use, distribution, and reproduction in any medium, provided the original work is properly cited.

Peer-review history:

The peer review history for this paper can be accessed here:

http://www.sciencedomain.org/review-history. php?iid=738\&id=2\&aid=6625 